\title{
Use of palatal prosthesis to correct an acquired palatal cleft in a cat: \\ a case report
}

\section{Utilização do obturador palatino para correção de fenda palatina adquirida em gato: relato de caso}

\author{
Luciano Jose Eigio Isaka ${ }^{1 *}$; Bruno Massa de Viveiros ${ }^{2}$; Luana Carpovicz \\ Carolina Haluche Lautert ${ }^{4}$; José Ademar Villanova Junior ${ }^{5}$
}

\section{Highlights:}

Forma de tratamento alternativa para tratamento de fendas palatinas.

Obturador palatino apresenta eficiência na oclusão e redução dos sintomas de fendas palatinas.

O obturador palatino apresenta eficiência no tratamento de fendas palatinas em felinos.

\begin{abstract}
Palatal malformations rarely occur in small animals. Palatal clefts can affect the upper lip, hard palate, and soft palate, and may be congenital or acquired in origin. The most common acquired forms result from the excision of oral neoplasia, teeth extraction, perforating lesions, automobile accidents, and electric accidents. Clinical signs of a fissured palate are sneezing, purulent nasal discharge, salivary secretion in nasal discharge, difficulty feeding and drinking, and pneumonia due to aspiration, which are the most severe alterations and can lead to death. The treatment of palatal clefts consists of occlusion of the oronasal communication, which can be performed using mucoperiosteal grafts, pedicled flaps, or palatal obturators. Herein, we report a case of an acquired palatal cleft treated with a palatal obturator in a feline patient who bit a high-tension wire. Two attempts of surgical correction had been unsuccessful, resulting in suture dehiscence and perpetuation of the oronasal fistula. After fixation of the obturator, the animal showed remission of all clinical signs. The animal has survived for over one year with improved quality of life.
\end{abstract}

Key words: Palate. Fistula. Palatal obturators.

\section{Resumo}

Os defeitos de palato são ocorrências raras na clínica de pequenos animais. As fendas palatinas podem afetar o lábio superior, palato duro e/ou palato mole, cuja origem pode ser congênita ou adquirida. As formas adquiridas mais comuns são excisão de neoplasias orais, exodontias, lesões perfurantes, acidentes automobilísticos e acidentes com choques elétricos. Os principais sintomas sinais clínicos são espirros, secreção nasal purulenta e salivar, dificuldade de alimentação e ingestão de água sendo a pneumonia

\footnotetext{
Prof. Dr., Universidade Positivo, UP, Curitiba, PR, Brasil. E-mail: luciano.isaka@gmail.com

Prof. M.e, Universidade Tuiuti do Paraná, UTP, Curitiba, PR, Brasil. E-mail: massabruno@hotmail.com

Médica Veterinária, Saúde Felina, Curitiba, PR, Brasil. E-mail: lucarpovicz@hotmail.com

Médica Veterinária, Curitiba, PR, Brasil. E-mail: hl_carolina@hotmail.com

Prof. Dr., Pontifícia Universidade Católica do Paraná, PUCPR, Curitiba, PR, Brasil, Brasil. E-mail: jose.villanova@pucpr.br

Author for correspondence
} 
por aspiração a alteração mais grave, podendo levar o animal a óbito. O tratamento das fendas consiste na oclusão da comunicação oronasal, que pode ser feita por meio de enxertos mucoperiosteias, flaps pediculados ou com uso de obturadores palatinos. O presente trabalho tem como objetivo relatar o uso de do obturador palatino como método de tratamento de fenda palatina adquirida, em um paciente felino, como causa foi por acidente com fio de alta tensão. Já haviam sido realizadas duas correções cirúrgicas que resultou em deiscência dos pontos e perpetuação da fistula oronasal. Após a fixação do obturador palatino o animal apresentou melhora de todos os sinais clínicos, e da qualidade de vida, e o período de avaliação já superou um ano.

Palavras-chave: Palato. Fístula. Fissura Palatina.

\section{Introduction}

A palatal cleft or fissure is a rare anomaly among companion animals, characterized by a communication between the nasal and oropharyngeal cavities (Radlinski, 2014).

The palate is located in the dorsal region of the oral cavity and is divided into the hard and soft palates. The hard palate stands rostrally to the soft palate and is composed of the incisive, maxillary, and palatal bones, with the overlying keratinized mucosa in which the palatal wrinkles are located. The soft palate is inserted caudally to the hard palate and is composed of non-keratinized mucosa. Both the palates are supplied by the palatal arteries and innervated by the vagus and glossopharyngeal nerves (Kelly \& Bardach, 2012).

Palatal alterations can be primary or secondary. Primary palatal clefts involve the lips, incisive bones, and premaxilla, known as leporine lips. Secondary fissures are characterized by incomplete closure of the hard palate, soft palate, or both (Radlinski, 2014).

The etiology of the cleft palate is associated with multiple factors, including congenital, hereditary, toxic (use of antifungals and contact with solvents or pesticides), infectious (toxoplasmosis), nutritional (hypervitaminosis A and D, vitamin B12, and folic acid deficiency), consanguinity, and stress, which lead to nonunion of the palatal bone plates in weeks 25-28 of pregnancy. Palatal fissures can also occur secondary to perforating traumas, gun fire, and electrical accidents, neoplasia, and periodontal and serious odontological diseases (Kelly \& Bardach, 2012).

Clinical signs of the disease are food spilling through the nostrils, salivary secretion in nasal discharge, coughing, sneezing, chronic rhinitis, halitosis, sialorrhea, weight loss, and pneumonia due to aspiration. The diagnosis is based on direct oral cavity inspection, mostly at birth or at the start of feeding (Nemec, Daniaux, Johnson, Peralte, \& Verstraete, 2015).

Isolated primary palatal clefts are repaired only for esthetics and may have systemic effects on the patient (Radlinski, 2014). Secondary clefts should be repaired because of potential respiratory worsening, which can lead to death (Radlinski, 2014).

Surgical techniques for palatal fissure correction aim to separate nasal and oropharyngeal cavities. Many techniques have been described, including the use of grafts (mucoperiosteal, pediculated, gingival, and lingual), auricular cartilage, bovine pericardium, and acrylic resin prosthesis (Kelly \& Bardach, 2012).

Suture dehiscence is the most common postoperative complication and mostly occurs because of high tension on the suture line, vascular injury, tongue movement above the suture line, and failure of closure because of a wide cleft. Success of the surgical procedure and the number of surgical interventions until complete fissure closing are mainly associated with the chosen technique, considering the extension and lesion width, since many techniques are limited by the absence of tissue 
available for closure (Radlinski, 2014).

In cases of failure to correct the defect with the traditional techniques, an acrylic-based prosthesis can be used as an alternative, placed directly over the fissure, occluding the communication between the cavities (Lee et al., 2006).

The prognosis is good in patients with small gaps, without systemic damage. These patients show greater surgical success rates. Respiratory complications are the main cause of death in animals with persistent fistulas (Radlinski, 2014).

Herein, we report a case of acquired palatal cleft in a cat with a history of failed palate repair surgeries.

\section{Case Report}

A 5-year-old male mixed-breed cat had bit a high-tension electrical wire 6 months before presentation, resulting in a palatal cleft. It had undergone two palatal repair surgeries using mucoperiosteal grafting, which had failed, resulting in the manifestation of clinical signs.

The owner reported clinical signs of choking after drinking or eating, salivary secretion in nasal discharge, occasional purulent nasal discharge, and chronic sneezing.

Clinical examination revealed a good body score, without systemic alterations. Intraoral examination revealed a palatal cleft, including the hard palate, measuring approximately $2 \mathrm{~cm}^{2}$ (Figure 1).

The animal had undergone two grafting procedures; therefore, a palatal prosthesis was chosen as the treatment. The patient presented with remaining surgical sutures at the cleft borders from the last reconstruction trial.

Preoperative serum biochemistry and thoracic radiography revealed no further alterations.

Intramuscular injections of $0.05 \mathrm{mg} \mathrm{kg} \mathrm{kg}^{-1}$ of acepromazine and $5 \mathrm{mg} \mathrm{kg}$ of ketamine were administered as pre-anesthetic medication. Subsequently, anesthesia was induced with intravenous administration of $5 \mathrm{mg} \mathrm{kg}^{-1}$ propofol and maintained with $2 \%$ isoflurane after intubation with a size 3 tracheal cuffed tube.

The palatal obturator was composed of a mold of the superior dental arch fabricated using fluid and heavy elastomer (Express $\square$ XT Putty Soft 3M $\mathrm{ESPE}^{\square}$ ). The mold was sent to a prosthodontist for the confection of a cut-to-fit obturator. For its fixation, the patient was anesthetized again using the same protocol. After asepsis with $2 \%$ chlorhexidine, $37 \%$ orthophosphoric acid was applied on the canine and fourth premolar, followed by prosthesis fixation using light-cure composite resin on the same teeth (Figure 2).

A pet cone was set postoperatively for approximately 3 weeks, until the patient fully adapted to the obturator. Antibiotic therapy was provided with spiramycin (75.000 UI kg-1) and metronidazole $\left(12.5 \mathrm{mg} \mathrm{kg}^{-1}\right)$ for 7 days, during which the clinical signs resolved. Commercial cat ration (softened with warm water) or pasty caned cat food was recommended for feeding. They were fully accepted by the patient, according to its owner. The animal is currently healthy, presenting with total resolution of the clinical signs, and is sedated every 6 months for obturator hygiene and fixation, if needed. 


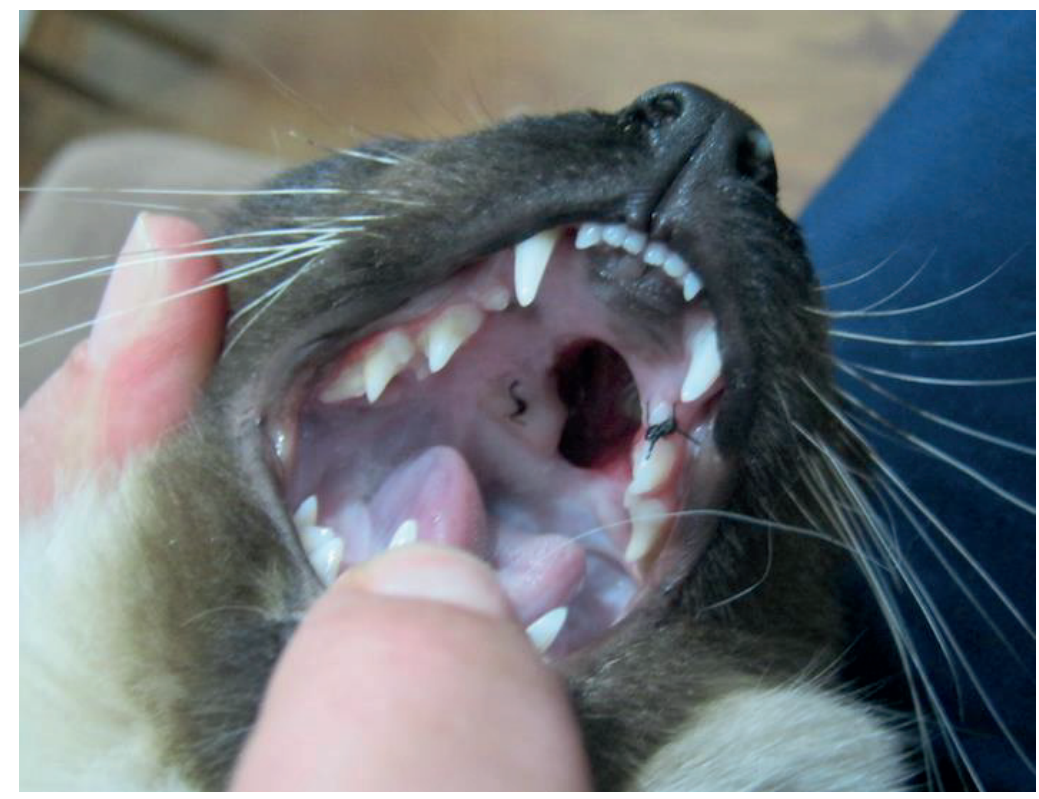

Figure 1. Acquired palatal cleft in a cat after biting a high-tension electrical wire. Surgical sutures remaining from the previous palatal repair surgery can be observed.

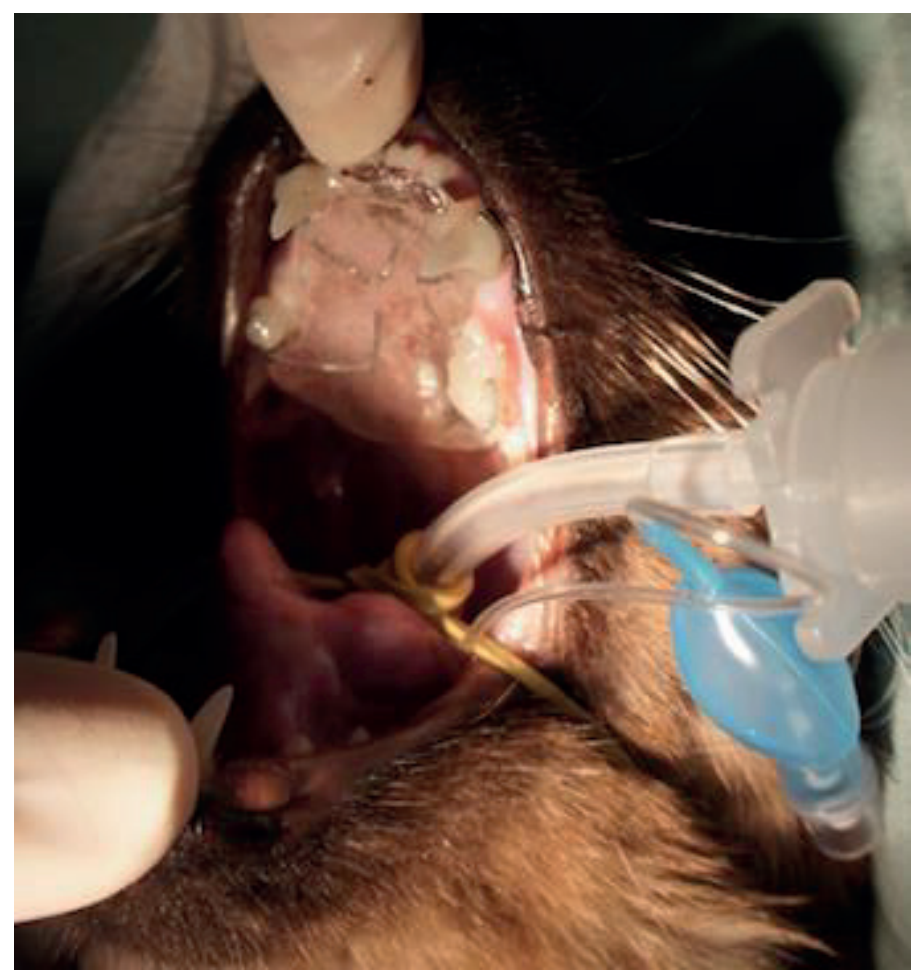

Figure 2. Final aspect of the closure of the acquired palatal cleft using an acrylic resin obturator.

\section{Discussion}

Palatal defects can have various causes, whether congenital or acquired. In the present case, electrical shock led to severe hard palate damage perpetuating the oronasal communication. Clinical signs in the patient, including rhinitis, nasal discharge, choking, and sneezing, are the main signs of a cleft, which can lead to aspiration pneumonia and death in severe 
cases. In the present case, the animal had clinical signs associated with water and food intake, as described by Lee et al. (2006), without respiratory alterations of relevance on thoracic radiography or serum biochemistry, ruling out pneumonia and infection.

Corrective palatal surgery has a high failure rate, especially due to a high incidence of suture dehiscence. The present patient had undergone two surgical interventions, none of which had been successful. According to Souza, Alfeld, Cicarella, Grilo and Castelan (2007) and Kelly and Bardach (2012), tension over the suture line, tongue movement, eating hard food, vascular injury, and local contamination are factors predisposing to suture dehiscence, which may have occurred in this case because of the large fissure dimensions. In cases of multiple unsuccessful surgical attempts, high risk of anesthetic complications because of the patient's health condition, or large cleft dimensions hindering grafting techniques, a palatal obturator composed of acrylic resin is indicated for adequate defect occlusion (Silva, Magalhães, Oliveira, Coelho, \& Saldanha, 2009).

Atallah et al. (2013) and Sousa, Sampaio, Evangelista and Cunha (2016) applied self-cure acrylic resin in the plastic phase directly above the defect and obtained favorable results, with resolution of clinical signs. The advantage of selfcure acrylic resins is the complete occlusion of the defect, filling all irregularities in the oral cavity; however, the exothermic phase of the resin can cause thermal damage to the mucosa, leading to necrosis of the nasal and oral cavities. Other limiting factors are poor esthetics and the difficulty in removing and cleaning the obturator, if necessary (Goelzer et al., 2003).

Lee et al. (2006) reported the use of a palatal obturator combined with a bone graft in a dog after two unsuccessful cleft closing procedures. For the fixation, instant glue and plastic bands were used, which had reported benefits of removing and fixing the obturator without anesthesia. They also reported the absence of clinical signs for 30 weeks, during which the animal remained with the prosthesis.

In this study, fixation was performed with lightcure acrylic resin for four teeth, which resulted in good fixation strength and easy maintenance of hygiene, since the animal's owner was averse to new attempts at grafting because of the size of the cleft.

The use of paste or water-softened food was satisfactory in the present case and did not damage the prosthesis, as reported by Sivacolundhu (2007).

\section{Conclusion}

A palatal obturator is a treatment option for acquired palatal clefts and may be utilized when previous surgical interventions have been unsuccessful.

\section{References}

Atallah, F. A., Estupinañ, O. F. T., Ramos, R. M., Vale, D. F., Silva, S. J. Q., Costa, D. R. G., Oliveira, A. L. A. (2013). Uso de resina acrílica na reconstrução do pala duro após exérese de carcinosa nasal em cães - relato de caso. Revista Brasileira de Medicina Veterinária, 35(Suppl. 1), 113-117.

Goelzer, L. P., Raiser, A. G., Gaiga, L. H., Brondani, J. T., Sheila, A. B., \& Camargo, F. (2003). Acrílico auto-polimerizável associado ou não a retalho mucoperiostal simples no tratamento de fístula oronasal experimental em cães. Arquivo Brasileiro de Medicina Veterinária e Zootecnia, 55(5), 550556. doi: 10.1590/S0102-09352003000500006

Kelly, K. M., \& Bardach, J. (2012). Biologic basis of cleft palate and palatal surgery. In F. J. M. Verstraete, \& M. J. Lommer (Eds.), Oral and maxillofacial surgery in dogs and cats (pp. 343-350). Edinburgh: Saunders Elsevier.

Lee, J., Kim, Y. S., Kim, M. J., Lee, J., Choi, J. H., Yeom, D. B., Hong, S. H. (2006). Application of a temporary palatal prosthesis in a puppy suffering from cleft palate. Journal of Veterinary Science, 7(1), 93-99. doi: 10.4142/jvs.2006.7.1.93 
Nemec, A., Daniaux, L., Johnson, E., Peralte, S., \& Verstraete, F. J. (2015). Craniomaxillofacial abnormalities in dogs with congenital palatal defects: computed tomographic findings. Veterinary Surgery, 44(4), 417-422. doi: 10.1111/j.1532950X.2014.12129.x.

Radlinski, M. G. (2014). Cirurgia da cavidade oral e da orofaringe. In T. W. Fossum, Cirurgia de pequenos animais (4a ed., Vol. 3, pp. 398-411). São Paulo: Roca.

Silva, L. M. R., Magalhães, F. J. R., Oliveira, A. M. A., Coelho, M. C. O. C., \& Saldanha, S. V. (2009). Redução de fenda palatina, secundária a tumor venéreo transmissível, com obturador palatino. Revista Portuguesa de Ciência Veterinária, 104(569572), 77-82.
Sivacolundhu, R. K. (2007). Use of local and axial pattern flaps for reconstruction of the hard and soft palate. Clinical Techniques in Small Animal Practice, 22(2), 61-69. doi: 10.1053/j.ctsap.2007.03.005

Sousa, R. P. de, F'., Sampaio, K. de O., Evangelista, J. S. A. M., \& Cunha, M. G. M. C. M. da. (2016). Oclusão de fístula oronasal em gato com uso somente de resina acrílica autopolimerizável. Arquivo de Ciências Veterinárias e Zoologia da Unipar, 19(2), 101-105. doi: 10.25110/arqvet.v19i2.2016.5929

Souza, H. J. M., Alfeld, F., Cicarella, L. C., Grilo, J. C., \& Castelan, F. G. (2007). Oclusão de fístula oronasal crónica utilizando a "U”-Plastia da mucosa palatal em gato. Acta Scientiae Veterinariae, 35(2), 474475 . 